\title{
Environmental Concerns of Russian Businesses: Top Company Missions and Climate Change Agenda
}

\author{
Tatyana K. Molchanova ${ }^{1,2}$, Natalia N. Yashalova ${ }^{3}$ and Dmitry A. Ruban ${ }^{2,4, * \mathbb{C}}$ \\ 1 National Research University Higher School of Economics, Moscow 119049, Russia; tkm_stud@mail.ru \\ 2 Southern Federal University, Rostov-on-Don 344019, Russia \\ 3 Cherepovets State University, Cherepovets 162600, Russia; natalij2005@mail.ru \\ 4 K.G. Razumovsky Moscow State University of Technologies and Management (the First Cossack University), \\ Moscow 109004, Russia \\ * Correspondence: ruban-d@mail.ru
}

Received: 7 March 2020; Accepted: 11 April 2020; Published: 13 April 2020

check for updates

\begin{abstract}
Climate change is on the national agenda of Russia due to this country's contribution to greenhouse gas emissions and the expected degree of warming and precipitation increase in its territory. A content analysis of the mission statements of the 100 biggest Russian companies shows that $18.5 \%$ of them deal with environmental issues. About half of the companies that declare pro-environmental behavior belong to the energy production and transmission industry. It also is found that more than $30 \%$ of all leading hydrocarbon, chemical, and mining companies express environmental concerns in their mission statements. The main environmental priorities declared by the top Russian companies include caring for nature, production ecologization, energy efficiency, and ecological standards. These priorities are related to climate-friendly behavior, but the latter is not stated directly. Direct consideration of climate change in the mission statements of Russian companies is recommended.
\end{abstract}

Keywords: business leader; content analysis; mission statement; pro-environmental behavior; warming

\section{Introduction}

Climate change is of utmost importance to modern society [1-7], and pro-environmental behavior, including climate-friendly actions, can be regarded as an efficient approach to address this challenge [8-13]. This behavior can be demonstrated by the general public [14-18], selected groups such as students [19-23], decision-makers [24-27], and business leaders [28-33].

Ideally, the broad public awareness of environmental and climate change problems and/or their media coverage not only contributes to pro-environmental behavior, but also triggers an acceleration of public pressure on policy-makers and business leaders to perform more ecologically balanced and climate-friendly actions (Figure 1). The functioning of such mechanisms is especially important for such countries as Russia. Russia possesses very rich natural resources, the exploitation of which provokes both environmental disturbance and greenhouse gas emissions [34-40], on the one hand. The geographical position of Russia in the northern part of Eurasia and close to the Arctic, where significant warming is expected, makes it one of the most climate-change-affected countries [2,4], on the other hand. 


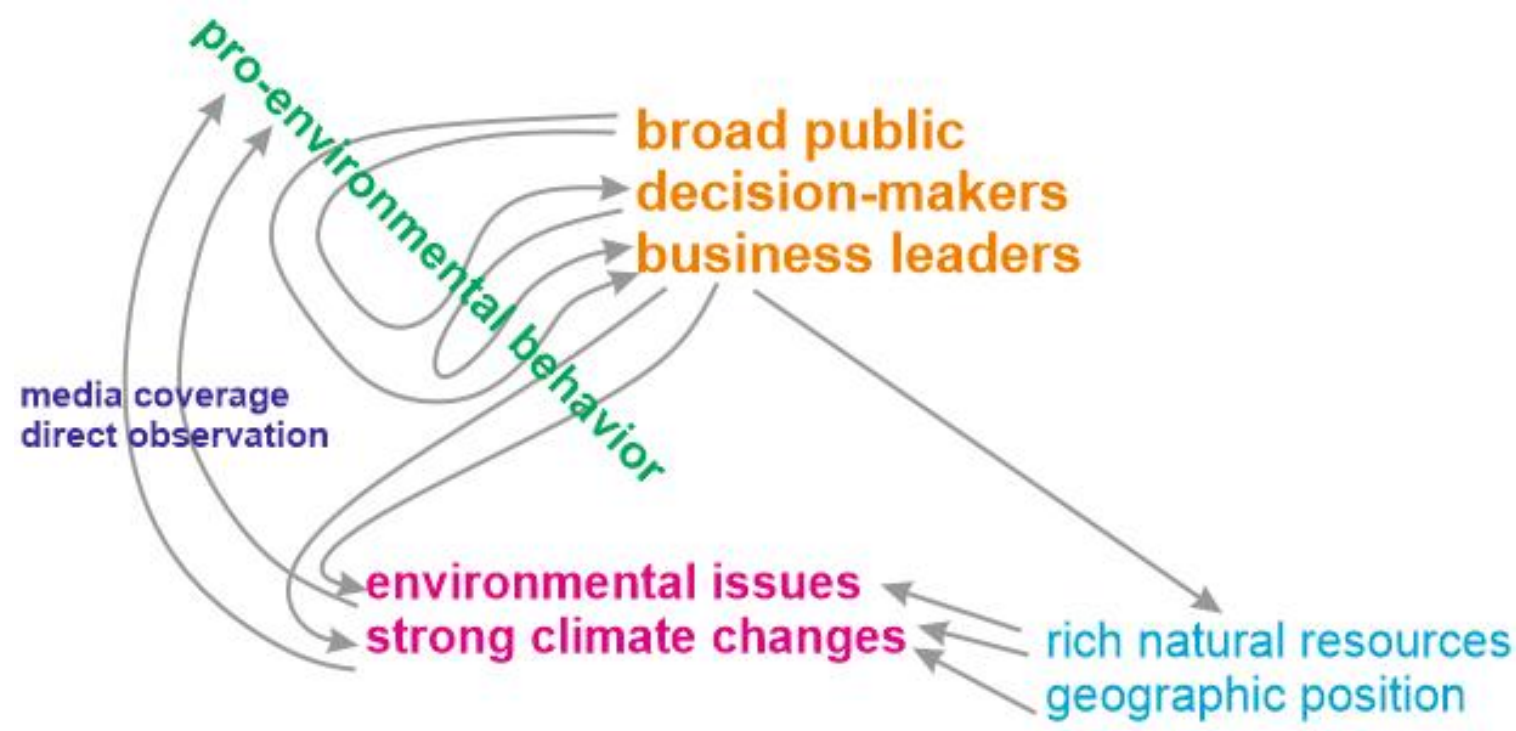

Figure 1. Conceptualization of some influence and feedback relevant to pro-environmental behavior.

Russia is responsible for $\sim 5 \%$ of global carbon dioxide emissions [34]. The century-long increase in annual temperatures expected for this country is $2-7^{\circ} \mathrm{C}$, and it is projected to reach $10{ }^{\circ} \mathrm{C}$ in the Arctic regions (optimistic scenarios also prescribe significant warming); precipitation may increase by $10-30 \%$, or even more [4]. This means that the development of pro-environmental behavior is very urgent for Russia. Different aspects of this issue have been discussed previously. Anisimova and Sadriev [41] found that energy consumption management as a constituent of pro-environmental behavior is not typical in the urban population of Russia. Chater [42] considered the positive side of Russian behavior in regard to Arctic environments and, particularly, the country's participation in the Arctic Council. Graves et al. [43] realized that the pro-environmental behavior of top managers stimulates the same behavior of employees in Russian companies. Hokka et al. [44] found that the environmental concerns of youth are very high in Moscow relative to those in some other European cities. Kovalev et al. [45] showed that the pro-environmental behavior of the public is able to influence decision-making in Russia. Porfiryev [46] argued that responsible energy consumption and environmental safety have become aspects of the behavior of modern Russians. A cross-cultural analysis permitted Schultz et al. [47] to prove the importance of self-transcendence values for environmental concern in Russia and other countries. Soyez [48] proposed that general humanistic appeals are able to facilitate an ecocentric approach in Russian society. Waylen et al. [49] concluded that the pro-ecological Buddhist teaching in one Russian region facilitated the pro-environmental behavior of the public. Finally, Zibenberg et al. [50] found that the behavior of Russian university students is linked to biospheric and self-direction values. It is worth adding that the current Presidential initiative, namely, the Ecology National Project (a combination of actions and relevant funding mechanisms to improve the environmental performance of the country within a few years), places environmental priorities among the top priorities of Russia.

The objective of the present study is the examination of environmental concerns reflected by the mission statements of the top Russian companies. Environmental concerns, in this case, are understood as company declarations related to nature protection, reduction of greenhouse emissions, etc., that are stated officially but voluntary, i.e., they are not just formal statements required by the national law or the existing policy practices (in other words, these concerns reflect the strategic thoughts of company managers). The two research questions are as follows. First, how much do top Russian companies address the environment in their mission statements and which issues do they tend to emphasize? Second, is climate change addressed in these statements directly or indirectly? To the authors' knowledge, this is the first study of this kind that is focused on Russia. Although this paper deals with environment- and climate-related issues, it also examines their economic (managerial) aspects and, thus, it follows the general style and methodology of the socio-economical literature. 
Theoretically, this study is linked to systems theory and the systems-based approach, which have important applications in management [51-57]. Particularly, mission statements are instruments of the interaction of companies and the business environment, and their formulation is one of several sequential steps toward the implementation of company priorities. Thus, basic principles (the openness of enterprises and managerial systems and step-by-step managerial actions) are addressed.

\section{Materials and Methods}

Missions are highly important elements of company strategies that reflect business priorities set by owners, CEOs, top managers, etc. It is known that these declarations influence real company performance [58-62]: i.e., these are not 'just words', but real instruments of strategic management. Commonly, mission statements are strategic documents, not public relation tools (although they may function as such, too). This is especially the case for big corporations, often employing business-to-business models that need well-fixed, professionally developed strategies.

Conceptualization of company missions and the relevant methodological advances were made in the seminal works by David [63], David and David [64], and Pearce and David [65]. These experts explained the purposes of missions in the modern world business, standardized the content of mission statements, and proposed the component-based analysis of these statements. Their developments formed a solid ground for mission statement analysis as an individual research direction that has become popular in managerial studies [66,67]. Although various aspects of mission statements are analyzed by different specialists, many pay attention to the presence of some specific components. Some words and phrases of a given mission statement, for instance, can be related to markets, while others are linked to employees, etc. Importantly, the pioneering paper by Pearce and David [65] deals with environmental issues in mission statements; particularly, these specialists related environmental statements to the company philosophy. The studies by Baral and Pokharel [68] and Garnett et al. [69] stress the importance of environmental analysis in strategic management research. It is also clear that the 'standard' components of mission statements [65] do not satisfy the needs of such analyses, as all environmental concerns can be easily attributed to the company philosophy as a principal component., Closer attention to the environment-related words and phrases in mission statements is necessary, if so. A proper methodology can be developed intuitively and tentatively for the purposes of a given study. Generally, the present paper follows the methodological principles of Pearce and David [65], i.e., qualitative analysis of mission statements by searching for 'standard' components, but it pays attention to specific, environment-related information and, thus, utilizes specific criteria.

Here, 100 Russian companies with the highest total value [70] are considered, i.e., these are the national business leaders chosen according to the highest capitalization. The online presence of mission statements was checked for each of them, and such declarations were found for 81 companies. It should be stressed that this study focuses on mission statements and not on entire company webpages, which serve chiefly for public relations purposes. The Russian versions of the mission statements are analyzed for two reasons. First, not all companies provide their strategic declarations in English. Second, the Russian versions are original by definition, and their English translations (especially literal) may or may not mean exactly the same. Regardless, all environment-related words and phrases have been carefully translated into English.

The content of each mission statement was examined with precision to find evidence of environment-related concerns. These may be notions (words and phrases) of ecological responsibility, caring for nature, energy efficiency, eco-innovations, etc. Evidently, these concerns reflect environmental priorities that should be understood as expressions of the pro-environmental behavior of Russian business leaders (or, at least, readiness for such behavior). Only companies with environmental concerns in their mission statements are considered in the present analysis (Table 1). The words and phrases (or parts of the phrases) relevant to these concerns were specified, extracted, and properly translated. This state-of-the-art, word-by-word analysis is the 'core' of the present study. The extracted information is then summarized, which allows for further case-sensitive categorization of the reported 
environmental concerns. This means the categories are identified intuitively on the basis of the diversity of the registered environmental notions. The categories are not pre-established, in other words. Indeed, this does not mean that the basic principle of the content analysis (the use of a priori analytical categories [71]) is violated. To contrast, the distribution of the established categories by mission statements is documented, which allows for an understanding of the relative importance of each type of environmental priority and, thus, for a 'mapping' of business leaders' pro-environmental behavior. The industries to which the considered companies belong are also considered. To avoid any unintentional violation of the companies' interest or reputation, all considered mission statements are treated anonymously.

Table 1. Top Russian companies with environmental components in their mission statements.

\begin{tabular}{|c|c|c|c|}
\hline Company & Industry & Place * & URL to Mission Statement \\
\hline Inter RAO & Energy & 21 & https://www.interrao.ru/upload/doc/Kodeks_korp_etiki.pdf \\
\hline Kazanorgsintez & Chemicals & 40 & https://www.kazanorgsintez.ru/about/missiya-i-strategiya.php \\
\hline NCSP & Transport & 45 & http://www.nmtp.info/upload/iblock/43f/PPIR.pdf \\
\hline Mosenergo & Energy & 54 & $\begin{array}{c}\text { http://www.mosenergo.ru/d/textpage/de/222/r99_year_2004_ } \\
\text { ch2_rus.pdf }\end{array}$ \\
\hline OGK-2 & Energy & 74 & https://www.ogk2.ru/rus/about/ \\
\hline $\begin{array}{l}\text { IDGC of Centre and } \\
\text { Volga Region }\end{array}$ & Energy & 81 & https://mrsk-cp.ru/about/mission_and_strategy/ \\
\hline $\begin{array}{c}\text { Kuzbasskaya } \\
\text { Toplivnaya Company }\end{array}$ & Mining & 91 & http://ktk.company/company/strategy \\
\hline TNS energo & Energy & 94 & https://corp.tns-e.ru/company/ \\
\hline IDGC of Urals & Energy & 95 & https://www.mrsk-ural.ru/investments-innovations/ims/ \\
\hline
\end{tabular}

\section{Results}

Considering 81 mission statements of the top Russian companies, only 15 statements (18.5\%) bear environmental components (Table 1). The majority of these companies belong to the group of the 25-100 biggest companies in the country by their total value, and only one company is among the 10 biggest companies (Table 1). Taken together, this evidence means that environmental concerns and, therefore, pro-environmental behavior are typical in a relatively narrow circle of Russian business leaders. However, these companies are national business leaders by definition, and their pro-environmental behavior can have strong and positive effects on the national business community. Moreover, the presence of the environmental component in $18.5 \%$ of the mission statements of the top Russian companies seems to be kind of the norm on a global scale. Only $14.8 \%$ of S\&P 500 companies, for instance, bear environmental components in their strategic statements [68].

The companies expressing environmental concerns in their mission statements represent five industries, namely, hydrocarbon production, mining (ore and coal), electric energy production and transmission, chemical production, and transport (Table 2). The majority of them belong to electric energy production and transmission (Figure 2). However, one should note that the environmental component is found in $33 \%$ of all top hydrocarbon companies that are among the most valued public Russian companies [70], 47\% of energy companies, $40 \%$ of chemical companies, $67 \%$ of mining 
companies, and $20 \%$ of transport companies. This means that pro-environmental behavior is quite typical in several important industries.

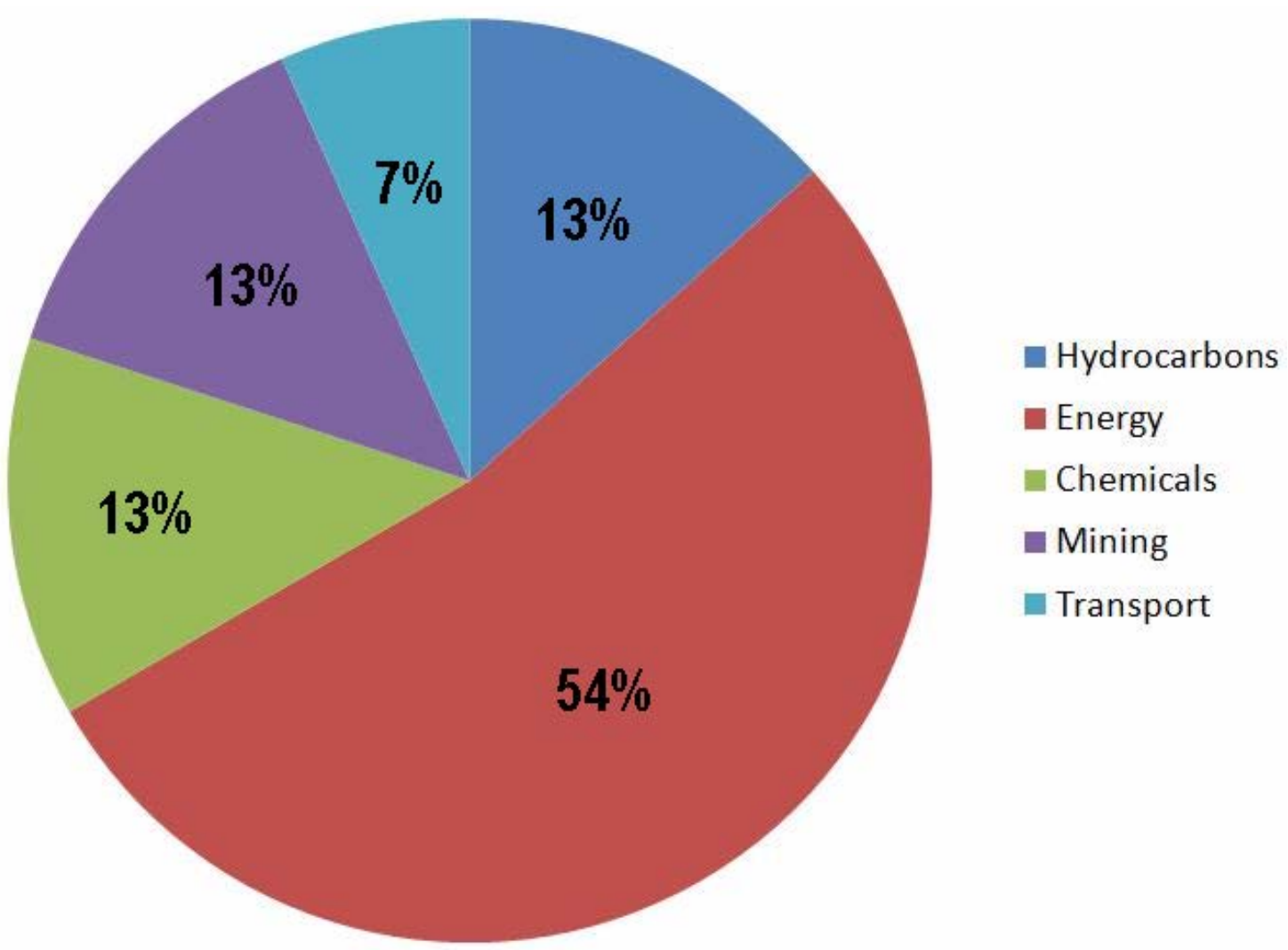

Figure 2. Distribution of registered environmental concerns by industry.

The environment-related notions in the analyzed mission statements are rather diverse (Table 2). However, some of them demonstrate a certain similarity and, thus, four categories (topics) can be delineated, namely, caring for nature, production ecologization (including renewable sources and ecological safety), energy efficiency, and ecological standards. Many statements deal with only one topic, although the simultaneous reflection of two or even three topics also is observed (Table 3). Generally, caring for nature is found in seven statements (47\%), product ecologization is registered in six cases $(40 \%)$, four statements deal with energy efficiency $(27 \%)$, and ecological standards are noted in four cases $(27 \%)$. Naturally, all notions of energy efficiency are typical in the energy companies, with only one exception. However, the mission statements in this industry tend to focus more on ecologization, and hydrocarbon and chemical companies tend to focus on caring for nature (Table 3). 
Table 2. Environment-related content of the considered mission statements.

\begin{tabular}{|c|c|c|}
\hline Company * & Industry & $\begin{array}{c}\text { Words and Phrases Linked to Environmental Concerns and } \\
\text { Translated from the Mission Statements ** }\end{array}$ \\
\hline A & Hydrocarbons & [working] "with care of environment" \\
\hline B & Energy & [sustainability] "via use of renewable energy sources" \\
\hline $\mathrm{C}$ & Energy & $\begin{array}{l}\text { "environmental protection, achievement of ecological safety of } \\
\text { production process" }\end{array}$ \\
\hline $\mathrm{D}$ & Energy & $\begin{array}{c}\text { [taking into account] "priorities of energy efficiency, ecological and } \\
\text { industrial safety" }\end{array}$ \\
\hline E & Energy & $\begin{array}{l}\text { [implementation of] "innovative technologies and solutions in the } \\
\text { sphere of energy efficiency and energy saving" }\end{array}$ \\
\hline F & Chemicals & $\begin{array}{l}\text { "to match high world ecological standards of interactions with ... } \\
\text { environment"; [achievement of] "the level of industrial and } \\
\text { economical safety matching legal requirements"; [doing all the best } \\
\text { for] "maximum reduction of negative influence on environment" }\end{array}$ \\
\hline G & Mining & [duty is] "matching the highest standards in the sphere of ecology" \\
\hline $\mathrm{H}$ & Energy & [providing] "ecologically-clean electrical energy" \\
\hline I & Energy & [use of] "equipment matching modern ecological standards" \\
\hline $\mathrm{J}$ & Transport & "increase in ecologization and energy efficiency" \\
\hline K & Energy & $\begin{array}{l}\text { "We provide the highest standards of environmental protection, } \\
\text { minimize negative influence on nature" }\end{array}$ \\
\hline $\mathrm{L}$ & Chemicals & "We care of soil fertility to encourage flourishing of life" \\
\hline M & Mining & [working with care for] "environment conservation" \\
\hline $\mathrm{N}$ & Hydrocarbons & "care of natural resources" \\
\hline $\mathrm{O}$ & Energy & "we contribute to energy efficiency of big industrial enterprises" \\
\hline
\end{tabular}

Notes: * All considered mission statements are treated anonymously, i.e., these statements are not associated with company names to avoid any violation of the real companies' interests. The order of the companies in this table, for this purpose, does not follow that in Table $1 .{ }^{* *}$ Words given in square brackets indicate the general relevance of the following quoted phrase (this approach is preferred to avoid providing the entire mission translation and occasional disclosure of the company name).

Table 3. Distribution of the principal environmental topics by the considered mission statements.

\begin{tabular}{|c|c|c|c|c|c|}
\hline \multirow{2}{*}{$\begin{array}{c}\text { Company } \\
\text { (See Table 2) }\end{array}$} & \multirow[b]{2}{*}{ Industry } & \multicolumn{4}{|c|}{ Environmental Topics (Interpreted on the Basis of Table 2) } \\
\hline & & $\begin{array}{l}\text { Care for } \\
\text { Nature }\end{array}$ & $\begin{array}{c}\text { Production } \\
\text { Ecologization }\end{array}$ & $\begin{array}{c}\text { Energy } \\
\text { Efficiency }\end{array}$ & $\begin{array}{l}\text { Ecological } \\
\text { Standards }\end{array}$ \\
\hline A & Hydrocarbons & + & & & \\
\hline B & Energy & & + & & \\
\hline C & Energy & + & + & & \\
\hline $\mathrm{D}$ & Energy & & + & + & \\
\hline $\mathrm{E}$ & Energy & & & + & \\
\hline $\mathrm{F}$ & Chemicals & + & + & & + \\
\hline G & Mining & & & & + \\
\hline $\mathrm{H}$ & Energy & & + & & \\
\hline I & Energy & & & & + \\
\hline $\mathrm{J}$ & Transport & & + & + & \\
\hline $\mathrm{K}$ & Energy & + & & & + \\
\hline $\mathrm{L}$ & Chemicals & + & & & \\
\hline M & Mining & + & & & \\
\hline $\mathrm{N}$ & Hydrocarbons & + & & & \\
\hline $\mathrm{O}$ & Energy & & & + & \\
\hline
\end{tabular}


The evidence given above means that the top Russian companies tend to focus on different aspects of pro-environmental behavior, although some coherence among their priorities is also clear. Importantly, many registered notions are not too philosophical but address technological processes and regulations, which is evidence of the 'mature' pro-environmental thinking of national business leaders. An important question is whether this is only rhetoric or if it amounts to real actions. An attitude-behavior gap is common [72]. Some companies may use the globally popular theme of ecology to enhance their image but not to solve real problems. Apparently, corporations responsible for significant environmental pressure may use mission statements to communicate their positive image (although this option does not seem to be too common, as mission statements are not the only public relations tool). Although it would be hard to answer the noted question without corporate reports on environmental performance (these reports are unavailable/closed in some if not many cases), it is necessary to note that mission statements play several roles, and these send particular 'signals' to managers and staff on how they should perform. The very statement of environmental concerns stimulates pro-environmental behavior, if so. Moreover, maintaining the image of companies through environmental concerns is a questionable approach: they may easily attract significant attention to what is really not done; it is hypothesized that managers of big corporations are aware of this risk.

\section{Discussion and Conclusions}

Modern studies of Russian businesses have paid significant attention to environmental aspects. These include economy ecologization on national [73] and regional [74] levels, waste management [75], energy use shifts [76], and environmental information disclosure [77]. Many of these works discuss potential and opportunities and, thus, the present study contributes to this knowledge by providing some factual information about the current state of the environmental concerns of the leaders of the Russian business community. The registered concerns reflect pro-environmental behavior, if it is assumed that the priorities declared in the company missions are followed strictly. However, how is this behavior relevant to the national climate change agenda?

Russia is both a contributor to climate change [34] and a possible victim of it [2,4]. None of the environmental concerns name the climate change issue directly (Table 2), but the recognized topics highlight priorities that are linked to this issue. Caring for nature reflects a kind of philosophical treatment of the environment's vulnerability to the anthropogenic pressure and ecological responsibility of the business community. Such a concern is vital to make business leaders ready for climate-friendly actions. Production ecologization means emphasizing technological adaptations to ecological needs, including climate change-related innovations. The very purpose of energy efficiency solutions is linked to the minimization of not only environmental but also climate change impacts of production (probably even despite economic costs). Therefore, the attention paid to this issue by several Russian business leaders indicates their awareness of climate change challenges and the relevant actions required. Even if energy efficiency can be a tool of cost reduction for some companies, i.e., an economic instrument and not an ecological one, the application of the latter still contributes to climate change mitigation. Finally, an appreciation of ecological standards stresses the companies' readiness to perform under ecological regulations (these are often based on climate change concerns) established by the state or international agreements.

It can be proposed that corporate environmental concerns expressed in the mission statements of the top Russian companies can increase the business community's awareness of the climate change problem. These concerns also form a valuable basis for the future decrease in the Russian contribution to global greenhouse gas emissions and the enhancement of adaptations to climate change in the territory of the country. However, the available mission statements allow for the achievement of these highly important tasks only indirectly, i.e., through some general environmental concerns; this fact limits the efficacy of these statements in promoting climate-friendly behavior and makes reasonable their subsequent change. 
All told, this brief, empirical analysis has three principal outcomes. First, less than $20 \%$ of the top Russian companies include environmental priorities in their mission statements, although these are business leaders with an outstanding influence on the national economy. Second, the analyzed mission statements demonstrate a diversity of pro-environmental behavior that can be expected if the companies follow their mission statements. Third, all environmental concerns of these Russian business leaders can be linked to the climate change issue (but such links need to be realized by the companies themselves). Generally, the results of this study provide tentative evidence of the readiness of some Russian business leaders to exhibit pro-environmental behavior. Even if the mission statements reflect only intentions, they seem to be important as a kind of 'information pressure' on the entire business community, i.e., as triggers of environmental and climate change awareness in the community.

The results of the present study allow two important practical recommendations to be made for all Russian companies. First, attention to environmental issues should be given more actively (the mission statements of many companies do not consider these issues). Second, the national agenda requires direct consideration of climate change in the mission statements of companies, especially those responsible for significant greenhouse gas emissions. The aim of the current state-level ecological initiatives realized in the country is to strengthen the pro-environmental and climate-friendly attitudes of companies within less than a decade. Further investigations of environmental concerns of Russian businesses can focus on the motivations of managers responsible for strategy development. Indeed, the environment can be considered differently (rational use of natural resources, waste management, attempts to gain state support, better economic performance, image development, etc.). The relevant attitudes of Russian managers can be examined via questionnaires and interviews, which require new research project(s).

Author Contributions: Conceptualization, N.N.Y. and D.A.R.; methodology, T.K.M. and D.A.R.; formal analysis, T.K.M.; writing, N.N.Y. and D.A.R.; project administration, N.N.Y. All authors have read and agreed to the published version of the manuscript.

Funding: The reported study was funded by RFBR according to the research project No. 18-010-00549.

Acknowledgments: The authors gratefully thank the editorial team and the reviewers for their support and precious recommendations.

Conflicts of Interest: The authors declare no conflict of interest. All considered mission statements are treated anonymously, i.e., these are not associated with the company names to avoid any violence of the real companies' interests.

\section{References}

1. Boto-García, D.; Bucciol, A. Climate change: Personal responsibility and energy saving. Ecol. Econ. 2020, 169, 106530. [CrossRef]

2. Giorgi, F. Climate change hot-spots. Geophys. Res. Lett. 2006, 33, L08707. [CrossRef]

3. Houghton, J. Global Warming. The Complete Briefing; Cambridge University Press: Cambridge, UK, 2009.

4. IPCC. Climate Change 2014: Synthesis Report; IPCC: Geneva, Switzerland, 2014.

5. Karl, T.R.; Trenberth, K.E. Modern Global Climate Change. Science 2003, 302, 1719-1723. [CrossRef] [PubMed]

6. Solomon, S.; Plattner, G.-K.; Knutti, R.; Friedlingstein, P. Irreversible climate change due to carbon dioxide emissions. Proc. Natl. Acad. Sci. USA 2009, 106, 1704-1709. [CrossRef]

7. Trenberth, K.E. Changes in precipitation with climate change. Clim. Res. 2011, 47, 123-138. [CrossRef]

8. Jakucionyte-Skodiene, M.; Dagiliute, R.; Liobikiene, G. Do general pro-environmental behaviour, attitude, and knowledge contribute to energy savings and climate change mitigation in the residential sector? Energy 2020, 193, 116784. [CrossRef]

9. Lin, S.-P. The gap between global issues and personal behaviors: Pro-environmental behaviors of citizens toward climate change in Kaohsiung, Taiwan. Mitig. Adapt. Strateg. Glob. Chang. 2013, 18, 773-783. [CrossRef]

10. Sapiains, R.; Beeton, R.J.S.; Walker, I.A. Individual responses to climate change: Framing effects on pro-environmental behaviors. J. Appl. Soc. Psychol. 2016, 46, 483-493. [CrossRef] 
11. Wynveen, C.J.; Sutton, S.G. Engaging the public in climate change-related pro-environmental behaviors to protect coral reefs: The role of public trust in the management agency. Mar. Policy 2015, 53, 131-140. [CrossRef]

12. Yu, T.-K.; Lin, F.-Y.; Kao, K.-Y.; Chao, C.-M.; Yu, T.-Y. An innovative environmental citizen behavior model: Recycling intention as climate change mitigation strategies. J. Environ. Manag. 2019, 247, 499-508. [CrossRef]

13. Lange, F.; Dewitte, S. Measuring pro-environmental behavior: Review and recommendations. J. Environ. Psychol. 2019, 63, 92-100. [CrossRef]

14. Briscoe, M.D.; Givens, J.E.; Hazboun, S.O.; Krannich, R.S. At home, in public, and in between: Gender differences in public, private and transportation pro-environmental behaviors in the US Intermountain West. Environ. Sociol. 2019, 5, 374-392. [CrossRef]

15. Hsu, J.L.; Feng, C.-H. Evaluating environmental behaviour of the general public in Taiwan: Implications for environmental education. Int. J. Comp. Educ. Dev. 2019, 21, 79-189. [CrossRef]

16. Liao, J.; Wang, Q. An empirical study on the public's environmental protection behavior and related factors. J. Environ. Account. Manag. 2017, 5, 201-209. [CrossRef]

17. Rajapaksa, D.; Islam, M.; Managi, S. Pro-environmental behavior: The role of public perception in infrastructure and the social factors for sustainable development. Sustainability 2018, 10, 937. [CrossRef]

18. Wan, C.; Shen, G.; Choi, S. An indirect pro-environmental behavior: Public support for waste management policy. Waste Manag. 2017, 69, 1-2. [CrossRef] [PubMed]

19. Janmaimool, P.; Khajohnmanee, S. Roles of environmental system knowledge in promoting university students' environmental attitudes and pro-environmental behaviors. Sustainability 2019, 11, 4270. [CrossRef]

20. Karasmanaki, E.; Tsantopoulos, G. Exploring future scientists' awareness about and attitudes towards renewable energy sources. Energy Policy 2019, 131, 111-119. [CrossRef]

21. Kukkonen, J.; Kärkkäinen, S.; Keinonen, T. Examining the relationships between factors influencing environmental behaviour among university students. Sustainability 2018, 10, 4294. [CrossRef]

22. Shafiei, A.; Maleksaeidi, H. Pro-environmental behavior of university students: Application of protection motivation theory. Glob. Ecol. Conserv. 2020, 22, e00908. [CrossRef]

23. Thondhlana, G.; Hlatshwayo, T.N. Pro-environmental behaviour in student residences at Rhodes University, South Africa. Sustainability 2018, 10, 2746. [CrossRef]

24. Dicks, L.V.; Walsh, J.C.; Sutherland, W.J. Organising evidence for environmental management decisions: A '4S' hierarchy. Trends Ecol. Evol. 2014, 29, 607-613. [CrossRef]

25. Fredriksson, P.G.; Wang, L.; Mamun, K.A. Are politicians office or policy motivated? The case of U.S. governors' environmental policies. J. Environ. Econ. Manag. 2011, 62, 241-253. [CrossRef]

26. Hilton, D.; Treich, N.; Lazzara, G.; Tendil, P. Designing effective nudges that satisfy ethical constraints: The case of environmentally responsible behaviour. Mind Soc. 2018, 17, 27-38. [CrossRef]

27. Worcester, R.M. Public and élite attitudes to environmental issues. Int. J. Public Opin. Res. 1993, 5, 315-334. [CrossRef]

28. Jitrumluek, P.; Falcioni, R.; Thiengkamol, N.; Thiengkamol, T.K. Entrepreneur's pro-environmental behavior: The mediating role of corporate social responsibility. J. Behav. Sci. 2019, 14, 14-27.

29. Lévy, M.; Eskew, M.; Bernotat, W.H.; Barner, M. Who owns the long term? Perspectives from global business leaders. Harvard Bus. Rev. 2007, 85, 54-60.

30. Lindell, M.; Karagozoglu, N. Corporate environmental behaviour - a comparison between nordic and US firms. Bus. Strategy Environ. 2001, 10, 38-52. [CrossRef]

31. Liu, Y.; Li, F.; Su, Y. Critical Factors Influencing the Evolution of Companies' Environmental Behavior: An Agent-Based Computational Economic Approach. SAGE Open 2019, 9. [CrossRef]

32. Walker, B.; Redmond, J. Changing the environmental behaviour of small business owners: The business case. Aust. J. Environ. Educ. 2015, 30, 254-268. [CrossRef]

33. Young, S.; Gates, S. Institutional investors' power to change corporate behavior: An introduction. Crit. Stud. Corp. Responsib. Gov. Sustain. 2013, 5, 3-16.

34. Each Country's Share of $\mathrm{CO}_{2}$ Emissions. Available online: https://www.ucsusa.org/resources/each-countrysshare-co2-emissions (accessed on 30 January 2020).

35. Meshcheryakov, S.V. Environmental problems in the fuel-energetics complex of Russia. Chem. Technol. Fuels Oils 2000, 36, 78-81. [CrossRef] 
36. Oberschelp, C.; Pfister, S.; Raptis, C.E.; Hellweg, S. Global emission hotspots of coal power generation. Nat. Sustain. 2019, 2, 113-121. [CrossRef]

37. Shirov, A.A.; Kolpakov, A. Russian economy and mechanisms of global climate regulation. Zhournal Novoi Ekonomicheskoi Associacii 2016, 4, 87-110. [CrossRef]

38. Trunov, A.A. Deforestation in Russia and its contribution to the anthropogenic emission of carbon dioxide in 1990-2013. Russ. Meteorol. Hydrol. 2017, 42, 529-537. [CrossRef]

39. Statista.com. In Your view, What are the Three Most Important Environmental Issues Facing Russia Today? Available online: https://www.statista.com/statistics/869107/russia-most-important-environmental-issues/ (accessed on 30 January 2020).

40. Wu, W.; Ma, X.; Zhang, Y.; Li, W.; Wang, Y. A novel conformable fractional non-homogeneous grey model for forecasting carbon dioxide emissions of BRICS countries. Sci. Total Environ. 2020, 707, 135447. [CrossRef]

41. Anisimova, T.Y.; Sadriev, A.R. Energy awareness and conservation behavior of Russian residential households. J. Environ. Manag. Tour. 2016, 7, 559-570.

42. Chater, A. Explaining Russia's relationship with the Arctic Council. Int. Organ. Res. J. 2016, 11, 41-54.

43. Graves, L.M.; Sarkis, J.; Gold, N. Employee proenvironmental behavior in Russia: The roles of top management commitment, managerial leadership, and employee motives. Resour. Conserv. Recycl. 2019, 140, 54-64. [CrossRef]

44. Hokka, P.; Palosuo, H.; Zhuravleva, I.; Pärna, K.; Mussalo-Rauhamaa, H.; Lakomova, N. Anxiety about environmental hazards among teenagers in Helsinki, Moscow and Tallinn. Sci. Total Environ. 1999, 234, 95-107. [CrossRef]

45. Kovalev, N.; Köppel, J.; Drozdov, A.; Dittrich, E. Democracy and the environment in Russia. J. Environ. Assess. Policy Manag. 2009, 11, 161-173. [CrossRef]

46. Porfiryev, B.N. Alternative energy as a factor of ecological and energy security: Features of Russia. Econ. Reg. 2011, 2, 137-145. [CrossRef]

47. Schultz, P.W.; Gouveia, V.V.; Cameron, L.D.; Tankha, G.; Schmuck, P.; Franek, M. Values and their relationship to environmental concern and conservation behavior. J. Cross-Cult. Psychol. 2005, 36, 457-475. [CrossRef]

48. Soyez, K. How national cultural values affect pro-environmental consumer behavior. Int. Mark. Rev. 2012, 29, 623-646. [CrossRef]

49. Waylen, K.A.; Fischer, A.; McGowan, P.J.K.; Milner-Gulland, E.J. Interactions Between a Collectivist Culture and Buddhist Teachings Influence Environmental Concerns and Behaviors in the Republic of Kalmykia, Russia. Soc. Nat. Resour. 2012, 25, 1118-1133. [CrossRef]

50. Zibenberg, A.; Greenspan, I.; Katz-Gerro, T.; Handy, F. Environmental Behavior Among Russian Youth: The Role of Self-direction and Environmental Concern. Environ. Manag. 2018, 62, 295-304. [CrossRef]

51. Charlton, B.G.; Andras, P. What Is Management and What Do Managers Do? A Systems Theory Account. Philos. Manag. 2003, 3, 3-15. [CrossRef]

52. Davies, R.; Saunders, R. Applying systems theory to project management problems. Int. Int. J. Proj. Manag. 1988, 6, 19-26. [CrossRef]

53. Kast, F.E.; Rosenzweig, J.E. General systems theory: Applications for organization and management. J. Nurs. Adm. 1981, 11, 32-41. [CrossRef]

54. McDaniel, J.G. Human resource management: A systems-based approach. Optometry 2004, 75, $393-397$. [CrossRef]

55. Mcleod, R. Systems Theory and Information Resources Management: Integrating Key Concepts. Inf. Resour. Manag. J. 1995, 8, 5-15. [CrossRef]

56. Staniškis, J.K.; Katiliute, E. Unsustainability reduction in enterprises by incremental innovations implementation and management. J. Clean. Prod. 2019, 236, 117542. [CrossRef]

57. Valentinov, V. Materiality in natural resource management: A systems theory view. J. Environ. Plan. Policy Manag. 2017, 19, 323-326. [CrossRef]

58. Bart, C.K.; Baetz, M.C. The relationship between mission statements and firm performance: An exploratory study. J. Manag. Stud. 1998, 35, 823-853. [CrossRef]

59. Bart, C.K.; Bontis, N.; Taggar, S. A model of the impact of mission statements on firm performance. Manag. Decis. 2001, 39, 19-35. [CrossRef]

60. Cortés-Sánchez, J.D.; Rivera, L. Mission statements and financial performance in Latin-American firms. Bus. Theor. Pract. 2019, 20, 270-283. [CrossRef] 
61. Germain, R.; Cooper, M.B. How a customer mission statement affects company performance. Ind. Mark. Manag. 1990, 19, 47-54. [CrossRef]

62. Godoy-Bejarano, J.M.; Tellez-Falla, D.F. Mission Power and Firm Financial Performance. Lat. Am. Bus. Rev. 2017, 18, 211-226. [CrossRef]

63. David, F.R. How companies define their mission. Long Range Plan. 1989, 22, 90-97. [CrossRef]

64. David, F.R.; David, F.R. It's time to redraft your mission statement. Bus. Strategy 2003, 24, 11-14. [CrossRef]

65. Pearce, J.A.; David, F. Corporate Mission Statements: The Bottom Line. Acad. Manag. Exec. 1987, 1, $109-116$. [CrossRef]

66. Alegre, I.; Berbegal-Mirabent, J.; Guerrero, A.; Mas-Machuca, M. The real mission of the mission statement: A systematic review of the literature. J. Manag. Organ. 2018, 24, 456-473. [CrossRef]

67. Bartkus, B.; Glassman, M.; McAfee, R.B. Mission statements: Are they smoke and mirrors? Bus. Horiz. 2000, 43, 23-28. [CrossRef]

68. Baral, N.; Pokharel, M.P. How Sustainability Is Reflected in the S\&P 500 Companies' Strategic Documents. Organ. Environ. 2017, 30, 122-141.

69. Garnett, S.T.; Lawes, M.J.; James, R.; Bigland, K.; Zander, K.K. Portrayal of sustainability principles in the mission statements and on home pages of the world's largest organizations. Conserv. Biol. 2016, 30, 297-307. [CrossRef]

70. Rating of the Most Valued Public Russian Companies-2019. Available online: https://riarating.ru/infografika/ 20190129/630115992.html (accessed on 30 January 2020).

71. Sovacool, B.K.; Axsen, J.; Sorrell, S. Promoting novelty, rigor, and style in energy social science: Towards codes of practice for appropriate methods and research design. Energy Res. Soc. Sci. 2018, 45, 12-42.

72. Kollmuss, A.; Agyeman, J. Mind the Gap: Why do people act environmentally and what are the barriers to pro-environmental behavior? Environ. Educ. Res. 2002, 8, 239-260. [CrossRef]

73. Kamenik, L. Modernization of the Russian economy on the basis of resource recycling and eco-economic balance of business. Smart Innov. Syst. Technol. 2020, 138, 213-221.

74. Potravny, I.M.; Yashalova, N.N.; Gassiy, V.V.; Chávez Ferreyra, K.Y. The project approach for managing the environmentally oriented development of the regional economy. Econ. Reg. 2019, 15, 806-821. [CrossRef]

75. Nevskaya, M.A.; Seleznev, S.G.; Masloboev, V.A.; Klyuchnikova, E.M.; Makarov, D.V. Environmental and business challenges presented by mining and mineral processing waste in the Russian Federation. Minerals 2019, 9, 445. [CrossRef]

76. Loktionov, V.I. Business barriers to the Russian sustainable energy transition. Geopolit. Energy 2018, 40, 2-6.

77. Tkachenko, I.N.; Pervukhina, I.V.; Sokolovskaya, O.E. Environmental Disclosure as a Factor of Sustainable Development of the Russian Business. Lect. Notes Netw. Syst. 2020, 115, 628-635. 